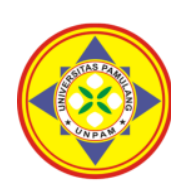

\title{
PENGARUH KUALITAS PRODUK FASTA DAN \\ KUALITAS PELAYANAN TERHADAP KEPUASAN PELANGGAN PADA RESTORAN PEPPER LUNCH CABANG CENTRAL PARK JAKARTA BARAT
}

\author{
${ }^{1 *}$ Hastono, ${ }^{2}$ Mila Diana \\ Universitas Pamulang, Tangerang Selatan, Banten, Indonesia \\ *dosen00340@unpam.ac.id
}

\begin{abstract}
Abstrak
Peneliti bertujuan untuk mengetahui pengaruh kualitas produk dan kualitas pelayanan secara simultan terhadap kepuasan pelanggan pada restoran pepper lunch cabang Central Park Jakarta Barat. Metode penelitian yang digunakan adalah kuantitatif. Teknik analisis data dalam penelitian ini adalah Uji Validitas dan Reliabilitas. Kemudian uji asumsi klasik meliputi uji normalitas, multikolinearitas, heteroskeastisitas, autokorelasi. Kemudian uji regresi linier sederhana, uji regresi linier berganda, korelasi product moment, dan koefisien determinasi, dan terakhir uji $\mathrm{t}$ dan uji $\mathrm{f}$ dalam pengujian hipotesis. Teknik pengambilan sampel yang digunakan dalam penelitian ini menggunakan rumus Slovin diperoleh sampel sebanyak 95 responden. Hasil penelitian menunjukkan bahwa kualitas produk (X1) dan kualitas pelayanan (X2) berpengaruh positif terhadap kepuasan pelanggan dengan persamaan regresi $\mathrm{Y}=-0,624+0,573 \mathrm{X} 1+0,422 \mathrm{X} 2$. Hasil analisis regresi. Tingkat hubungan antara variabel pengaruh kualitas produk dan kualitas pelayanan terhadap kepuasan pelanggan adalah 0,807 atau sangat kuat. Pengujian hipotesis dengan menggunakan uji statistik diperoleh nilai $\mathrm{F}$ hitung $>\mathrm{F}$ tabel atau $(86,195>2,72)$ hal ini diperkuat dengan nilai probabilitas signifikansi sebesar $0,000<0,05$, untuk itu hipotesis ketiga yang menyatakan bahwa terdapat pengaruh positif dan signifikan secara simultan antara kualitas produk dan kualitas layanan untuk kepuasan pelanggan, dapat diterima.
\end{abstract}

Kata Kunci: Kualitas Produk, Kualitas Pelayanan dan Kepuasan Pelanggan

\section{Abstract}

The researcher aims to determine the effect of product quality and service quality simultaneously on customer satisfaction at the pepper lunch restaurant, Central Park West Jakarta branch. The research method used is quantitative. The data analysis technique in this research is Validity and Reliability Test. Then the classical assumption test includes normality test, multicollinearity, heteroskeasticity, auto correlation. Then simple linear regression test, multiple linear regression test, product moment correlation, and coefficient of determination, and finally $t$ test and $f$ test in hypothesis testing. Sampling technique used in this study using the Slovin formula obtained a sample of 95 respondents. The results showed that product quality (X1) and service quality (X2) had a positive effect on customer satisfaction with the regression equation $Y=-0.624+0.573 X 1+0.422 X 2$. Regression analysis results. The level of relationship between the variables of the influence of product quality and service quality on customer satisfaction is 0.807 or very strong. Hypothesis testing using statistical tests obtained $F$ arithmetic value $>$ F table or $(86.195>2.72)$ this is reinforced by a significance probability value of $0.000<0.05$, for that the third hypothesis which states that there is a simultaneous positive and significant effect between quality product and service quality to customer satisfaction, is acceptable.

Keywords: Product Quality, Service Quality and Customer Satisfaction

\section{PENDAHULUAN}

Pelanggan merupakan asset sekaligus satu - satunya yang menilai baik atau buruknya kualitas produk dan kualitas layanan di restoran tersebut. Oleh karena itu salah satu syarat yang harus dipenuhi oleh restoran agar mencapai kesuksesan dan kelangsungan hidupnya adalah berusaha untuk menciptakan kenyamanan, ketepatan, keamanan dan kepuasaan bagi para pelanggan sesuai dengan jasa yang ditawarkannya. Dengan demikian setiap 
restoran mampu untuk memahami perilaku pada konsumen. Kualitas pelayanan dapat diartikan sebagai upaya pemenuhan kebutuhan dan keinginan

konsumen serta ketepatan penyampaiannya dalam mengimbangi harapan konsumen menurut (Tjiptono, 2010 :123).

Namun pada akhirnya dewasa ini banyak sekali ditemukan pelanggan yang masih mengeluhkan mengenai pelayanan yang diberikan oleh restoran pepper lunch

Tabel 1. Data Keluhan Pelanggan Terhadap Kualitas Pelayanan Periode Tahun 2017-2019

\begin{tabular}{|c|c|c|c|c|c|c|}
\hline \multirow[b]{2}{*}{ No } & \multirow{2}{*}{ Keluhan } & \multicolumn{3}{|c|}{ Tahun } & \multirow{2}{*}{ Jumlah } & \multirow{2}{*}{$\begin{array}{c}\text { Persentase } \\
(\%)\end{array}$} \\
\hline & & 2017 & 2018 & 2019 & & \\
\hline 1 & Kenyaman tempat kurang luas & 15 & 18 & 20 & 53 & $3 \%$ \\
\hline 2 & Kurangnya kecepatan dalam penyajian & 22 & 25 & 28 & 75 & $5 \%$ \\
\hline 3 & $\begin{array}{c}\text { Kualitas pelayanan dari karyawan } \\
\text { kurang baik }\end{array}$ & 24 & 28 & 31 & 83 & $6 \%$ \\
\hline
\end{tabular}

Sumber: Restaurant Papper Lunch Central Park Jakarta Barat

Berdasarkan data diatas dapat disimpulkan bahwa terdapat 53 keluhan pelanggan atas Kenyaman tempat kurang luas, 75 keluhan atas Kurangnya kecepatan dalam penyajian, 83 keluhan atas kualitas pelayanan karyawan kurang baik.Pada dasarnya posisi pelayanan merupakan faktor pendukungterhadapaktivitas pemasaran. Jika pelayanan yang diberikan memenuhi permintaan pelanggan, maka pelanggan akan merasa puas dan apabila pelayanan berada di bawah tingkat yang di harapkan maka pelanggan akan merasa

kurang/tidak puas. Pelanggan yang tidak puas terhadap kualitas pelayanan yang diberikan dengan sendirinya akan menceritakan kepada orang lain sebagai komplain atas ketidakpuasannya.

Berangkat dari hal tersebut penurunan jumlah pelanggan pada restaurant dapat dilihat khususnya pada restaurant dapat dilihat khususnya pada Restoran pepper lunch central park jakarta periode tahun 2017 sampai dengan 2019 yaitu:

Tabel 2. Tabel Total Jumlah Pelanggan Restoran Pepper Lunch Central Park Jakarta Barat

\begin{tabular}{|c|c|c|c|}
\hline \multirow{2}{*}{ Bulan } & \multicolumn{3}{|c|}{ Tahun } \\
\cline { 2 - 4 } & $\mathbf{2 0 1 7}$ & $\mathbf{2 0 1 8}$ & $\mathbf{2 0 1 9}$ \\
\hline Januari & 162 & 156 & 113 \\
\hline Februari & 137 & 142 & 194 \\
\hline Maret & 172 & 161 & 203 \\
\hline April & 167 & 167 & 162 \\
\hline Mei & 143 & 157 & 133 \\
\hline Juni & 153 & 124 & 157 \\
\hline Juli & 183 & 149 & 205 \\
\hline Agustus & 161 & 140 & 159 \\
\hline September & 159 & 162 & 143 \\
\hline Oktober & 134 & 159 & 171 \\
\hline November & 151 & 149 & 183 \\
\hline Desember & 168 & 166 & 197 \\
\hline Total pelanggan & 1900 & 2500 & 2020 \\
\hline
\end{tabular}

Sumber : Restoran Pepper Lunch Central Park jakarta Barat (2017-2019)

Berdasarkan data diatas dapat diketahui bahwa jumlah pelanggan pada 
tahun 2018 mengalami peningkatan dari tahun 2017 dengan jumlah total pelanggan 2500 pelanggan, sedangkan pada tahun 2019 mengalami penurunan dengan jumlah total pelanggan 2020 pelanggan.

Penjualan disuatu perusahaan Untuk mengingat perkembangan suatu usaha tergantung pada hasil penjualan yang merupakan sumber utama perolehan laba perusahaan. Maka pengelolaan kualitas produk dan kualitas layanan harus dilakukan secara terencana dan konseptual.

Kualitas pelayanan memiliki hubungan yang erat dengan kepuasan konsumen. Kualitas memberikan suatu dorongan kepada konsumen untuk menjalin ikatan hubungan yang kuat dengan perusahaan Kualitas pelayanan juga menjadi salah satu kunci utama keberhasilan. Hal tersebut sepaham dengan pendapat kualitas pelayanan menurut (Lupiyoadi dan Hamdani, 2010:175-181) dimana kualitas pelayanan adalah upaya pemenuhan kebutuhan dan keinginan pelanggan serta ketepatan penyampaiannya untuk mengimbangi harapan pelanggan.

Restoran yang menerapkan strategi dalam hal pelayanan terhadap konsumen adalah Restoran pepper lunch yang ada di central park jakarta barat, yang bergerak dijasa pelayanan dan penjualan produk makanan bagi masyarakat di sekitar wilayah central park jakarta barat. Restoran pepper lunch dalam usahanya memberikan produk yang berkualitas dan jasa pelayanan yang memuaskan bagi para pelanggannya, dalam arti tidak mengecewakan para pelanggannya, tepai dalam operasionalnya, Restoran ini sering terjadi kelambatan dan kesalahan dalam hal penyajian produk dan jasa pelayanan kepada tamu, sehingga timbul adanya keluhan dari pelanggan terhadap penyajian produk. Berdasarkan paparan diatas, maka penulis tertarik untuk melakukan penelitian dengan judul "Pengaruh Kualitas Produk Fasta Dan Kualitas Pelayanan Terhadap Kepuasan Pelanggan Pada Restoran Pepper Lunch Cabang Central Park Jakarta Barat".

\section{TINJAUAN PUSTAKA}

1. Manajemen

Menurut Anoraga (2013:109) berpendapat "Manajemen adalah proses yang tindakan-tindakan perencanaan, pengorganisasian, pelaksanaan, dan pengendalian yang digunakan baik ilmu pengetahuan maupun keahlian dalam rangka usaha mencapai tujuan organisasi yang telah ditetapkan".

Sedangkan menurut Hasibuan (2012:11) berpendapat "Manajemen adalah ilmu dan seni mengatur proses pemanfaatan sumber daya manusia dan sumber-sumber lainnya secara efektif untuk mencapai suatu tujuan tertentu". Menurut Terry (2012:16) menjelaskan "Manajemen merupakan suatu proses atas tindakan tindakan perencanaan pengorganisasian, penggerakan, dan pengendalian untuk menentukan serta mencapai tujuan melalui pemanfaatan sumber daya manusia dan sumber daya lainnya.

Dari beberapa definisi diatas dapat penulis simpulkan dalam memahami manajemen tersebut, bahwa manajemen merupakan suatu proses yang terdiri dari rangkaian kegiatan, seperti perencanaan, pengorganisasian, penggerakan dan pengendalian atau pengawasan yang dilakukan untuk menetukan dan mencapai tujuan yang telah ditetapkan melalui pemanfaatan sumberdaya manusia dan sumberdaya lainnya

\section{Pemasaran}

Menurut Simamora (2012:149) berpendapat "Pemasaran memiliki arti yang sama sekali berbeda dengan penjualan". Pemasaran juga tidak sekedar periklanan dan bentuk-bentuk promosi lainnya, namun, setiap hari kita selalu menjadi sasaran pemasaran dari berbagai produk. Sedangkan menurut Kotler dan Keller (2013:5) mendefinisikan "Pemasaran adalah mengidentifikasi dan memenuhi kebutuhan manusia dan sosial".

Pendapat lain dikemukakan oleh American Marketing Association (AMA) 
Pemasaran adalah suatu fungsi organisasi dan serangkaian proses untuk

menciptakan,mengomunikasikan,dan memberikan nilai kepada pelanggan dan untuk mengelola hubungan pelanggan dengan cara yang menguntungkan organisasi dan pemangku kepentinganya".

Jadi, penulis berkesimpulan pemasaran merupakan hubungan timbal balik untuk menciptakan suatu pertukaran barang maupun jasa. Walaupun pertukaran hanyalah salah satu tahap dalam proses pemasaran, pengambilan keputusan bidang pemasaran ditujukan untuk menentukan produk, pasar, harga dan promosi.

\section{METODE}

1. Tempat Penelitian

Menurut Sugiyono tempat penelitian adalah "Sasaran ilmiah untuk mendapatkan data dengan tujuan dan kegunaan tertentu tentang sesuatu hal yang objektif". Perusahaan yang menjadi objek dalam penelitian ini adalah Restoran pepper lunch cabang Central Park Kav 28 L -236,Jalan Letjend.S.Parman, RT.12/RW.6, Tj. Duren Selatan, Kecamatan Grogol Petamburan, Kota Jakarta Barat, Daerah Khusus Ibukota Jakarta 1470.Telp (021) 2920025.

2. Waktu Penelitian

Waktu Penelitian ini dilaksanakan selama 3 (tiga) bulan yang dimulai dari Juni - Agustus 2020. Penelitian dilakukan secara bertahap diawali dengan proposal judul penelitian, seminar proposal, penyempurnaan materi, pembuatan instrumen, pengumpulan data primer dan skunder, penyebaran kuesioner, pengolahan data yang telah didapat oleh penulis dan penyusunan pelaporan hasil skripsi.

3. Populasi

Menurut Sugiyono (2017:215) mendefinisikan "Populasi adalah jumlah wilayah generalisasi yang terdiri atas obyek atau subyek yang mempunyai kualitas dan karakteristik yang ditetapkan oleh peneliti dan kemudian ditarik kesimpulannya". Menurut Jonathan Sarwono (2014:18), "Populasi merupakan kesatuan yang mempunyai karakteristik yang sama dimana sampel akan kita tarik". Menurut Suharsimi Arikunto (2016:173), "Populasi adalah keseluruhan subjek penelitian".

Berdasarkan yang telah peneliti tetapkan untuk di jadikan penelitian, maka yang menjadi populasi penelitian ini adalah pelanggan pada Restoran Pepper Lunch Cabang Central Park Jakarta Barat, berjumlah 2020 orang.

4. Sampel

Menurut Sugiyono (2017:215) yaitu "Sampel adalah jumlah dan karakteristik yang dimiliki oleh populasi tersebut". Sedangkan menurut Suharsini Arikunto (2016:131), berpendapat bahwa "Sampel adalah sebagian atau wakil populasi yang diteliti". Dari total populasi penelitian ini terdapat 95 responden yang memenuhi kriteria dalam penelitian ini.

5. Tehnik Sampling

Menurut Sugiyono (2017:81)

"Tehnik sampling merupakan tehnik pengambilan sampel untuk digunakan dalam penelitian". Dalam penelitian ini menggunakan probability sampling. Menurut Sugiyono (2017:118) probability sampling adalah "Teknik pengambilan sampling yang memberikan peluang yang sama bagi setiap anggota populasi untuk dipilih menjadi anggota sampel.

Menurut Sugiyono (2017:87)

"Dalam sebuah penelitian jika jumlah populasinya dianggap terlalu besar maka penulis dapat mempersempit populasi dengan cara menghitung ukuran sampel yang dilakukan dengan menggunakan teknik Slovin agar representatif dan hasilnya dapat digereralisasikan". Dengan demikian penentuan jumlah sampel dalam penelitian ini dilakukan dengan perhitungan sederhana memakai rumus slovin sebagai berikut: 


$$
\begin{aligned}
& n=\frac{\mathrm{N}}{1+N(e)^{2}} \\
& n=\frac{2020}{1+2020 \times(0,1)^{2}} \\
& n=\frac{2020}{1+2020 \times(0,01)^{2}} \\
& n=\frac{2020}{21,1}
\end{aligned}
$$

$\mathrm{n}=95,73$ (dibulatkan menjadi 95 responden) Jumlah populasi sebanyak 2020 pelanggan dengan sampel sebanyak 95,73 pelanggan dan untuk mempermudah penelitian maka responden di bulatkan sebanyak 95 responden. Taraf kesalahan dalam penelitian ini $10 \%$.

\section{HASIL DAN PEMBAHASAN}

1. Pengaruh Pengaruh Kualitas Produk $\left(X_{1}\right)$ Terhadap Kepuasan Pelanggan ( $Y$ )

Berdasarkan hasil statistik dapat diketahui variabel Pengaruh Kualitas produk $\left(X_{1}\right)$ memiliki tingkat hubungan sebesar 0,723 atau kuat terhadap Kepuasan pelanggan (Y) dengan kontribusi pengaruh sebesar 0,523 atau $52,3 \%$, hal ini menunjukkan bahwa Kualitas produkyang tinggi akan meningkatkan Kepuasan pelanggan. Pengujian hipotesis diperoleh $t$ hitung $>$ t tabel atau $(10,101>1,661)$ hal tersebut diperkuat dengan nilai signifikansi 0,000 $<0,05$, untuk itu hipotesis pertama yang menyatakan terdapat pengaruh yang positif dan signifikan secara parsial antara Pengaruh Kualitas produk terhadap Kepuasan pelanggan, dapat diterima.

2. Pengaruh Kualitas Pelayanan $\left(X_{2}\right)$ Terhadap Kepuasan Pelanggan (Y) Berdasarkan hasil analisis diketahui Kualitas Pelayanan $\left(X_{2}\right)$ memiliki tingkat hubungan sebesar 0,566 atau sedang terhadap Kepuasan pelanggan (Y) dengan kontribusi pengaruh sebesar 0,320 atau $32 \%$, hal ini menunjukkan bahwa kualitas pelayanan yang tinggi akan meningkatkan kepuasan pelanggan. Pengujian hipotesis diperoleh nilai $t_{\text {hitung }}>t_{\text {tabel }}$ atau $(6,613>1,661)$ hal tersebut diperkuat dengan nilai signifikansi $0,000<0,05$, untuk itu hipotesis kedua yang menyatakan terdapat pengaruh yang positif dan signifikan secara parsial antara kualitas pelayanan terhadap kepuasan pelanggan, dapat diterima.

3. Pengaruh Pengaruh Kualitas Produk $\left(X_{1}\right)$ dan Kualitas Pelayanan $\left(X_{2}\right)$ Terhadap Kepuasan Pelanggan (Y)

Berdasarkan hasil penelitian, menunjukkan bahwa Pengaruh Kualitas produk $\left(\mathrm{X}_{1}\right)$ dan Kualitas Pelayanan $\left(\mathrm{X}_{2}\right)$ berpengaruh positif terhadap Kepuasan pelanggan dengan persamaan regresi $Y$ $=-0,624+0,573 X_{1}+0,422 X_{2}$. Hasil analisis regresi. Tingkat hubungan antara variabel Pengaruh Kualitas produk dan Kualitas Pelayanan terhadap Kepuasan Pelanggan sebesar 0,807 atau sangat kuat dengan kontribusi pengaruh sebesar 0,652 atau 65,2\% sedangkan sisanya sebesar $34,8 \%$ dipengaruhi faktor lain. Pengujian hipotesis menggunakan uji statistik diperoleh nilai $\mathrm{F}$ hitung $>\mathrm{F}$ tabel atau $(86,195>2,72)$ hal ini diperkuat dengan nilai probability signifikansi 0,000 $<0,05$, untuk itu hipotesis ke tiga yang menyatakan terdapat pengaruh yang positif dan signifikan secara simultan antara Pengaruh Kualitas produk dan Kualitas Pelayanan terhadap Kepuasan Pelanggan, dapat diterima.

\section{PENUTUP}

\section{Kesimpulan}

Berdasarkan data tentang pengaruh Kualitas Produk Fasta dan Kualitas Pelayanan Terhadap Kepuasan Pelanggan pada Restoran Pepper Luch Cabang Central Park Jakarta Barat, dapat disimpulkan bahwa :

1. Kualitas produk fasta $\left(X_{1}\right)$ memiliki tingkat hubungan sebesar 0,723 atau kuat terhadap kepuasan pelanggan $(\mathrm{Y})$ dengan kontribusi pengaruh sebesar 0,523 atau 52,3\%, hal ini menunjukkan bahwa kualitas produk fasta yang tinggi akan meningkatkan kepuasan pelanggan. Pengujian hipotesis 
diperoleh $\mathrm{t}$ hitung $>\mathrm{t}$ tabel atau $(10,101>$ 1,661) hal tersebut diperkuat dengan nilai signifikansi $0,000<0,05$, untuk itu hipotesis pertama yang menyatakan terdapat pengaruh yang positif dan signifikan secara parsial antara kualitas produk terhadap kepuasan pelanggan, dapat diterima.

2. Kualitas pelayanan $\left(X_{2}\right)$ memiliki tingkat hubungan sebesar 0,566 atau sedang terhadap Kepuasan pelanggan (Y) dengan kontribusi pengaruh sebesar 0,320 atau $32 \%$, hal ini menunjukkan bahwa kualitas pelayanan yang tinggi akan meningkatkan kepuasan pelanggan. Pengujian hipotesis diperoleh nilai $t_{\text {hitung }}>t_{\text {tabel }}$ atau $(6,613>$ $1,661)$ hal tersebut diperkuat dengan nilai signifikansi 0,000 <0,05, untuk itu hipotesis kedua yang menyatakan terdapat pengaruh yang positif dan signifikan secara parsial antara kualitas pelayanan terhadap kepuasan pelanggan, dapat diterima.

3. Kualitas produk fasta $\left(X_{1}\right)$ dan kualitas pelayanan $\left(X_{2}\right)$ berpengaruh positif terhadap kepuasan pelanggan dengan persamaan regresi $Y=-0,624+0,573 X_{1}+$ $0,422 X_{2}$ hasil analisis regresi. Tingkat hubungan antara variabel Pengaruh kualitas produk fasta dan kualitas pelayanan terhadap kepuasan Pelanggan sebesar 0,807 atau sangat kuat dengan kontribusi pengaruh sebesar 0,652 atau 65,2\% sedangkan sisanya sebesar $34,8 \%$ dipengaruhi faktor lain. Pengujian hipotesis menggunakan uji statistik diperoleh nilai $\mathrm{F}$ hitung $>\mathrm{F}$ tabel atau $(86,195$ $>2,72$ ) hal ini diperkuat dengan nilai probability signifikansi $0,000<0,05$, untuk itu hipotesis ketiga yang menyatakan terdapat pengaruh yang positif dan signifikan secara simultan antara pengaruh kualitas produk dan kualitas pelayanan terhadap kepuasan pelanggan, dapat diterima.

\section{Saran}

Berdasarkan analisis dan kesimpulan bahwa kualitas pelayanan sangat berpengaruh terhadap kepuasan pelanggan pada Restoran Pepper Luch Cabang Central Park Jakarta Barat maka ada beberapa saran sebagai berikut:

1. Berdasarkan kuesioner diketahui indikator kualitas produk fasta, pada Restoran Pepper Luch Cabang Central Park Jakarta Barat memiliki nilai ratarata skor yang paling kecil yaitu sebesar 2,87. Oleh karna itu Restoran Pepper Luch Cabang Central Park Jakarta Barat harus lebih meningkatkan kualitas produk agar kepuasan pelanggan tetap terjamin melalui perbaikan karakteristik dan desain produk

2. Berdasarkan sebaran kuesioner diketahui indikator kualitas pelayanan pada Restoran Pepper luch cabang central park jakarta barat ini memiliki nilai rata-rata skor yang paling kecil yaitu sebesar 3,31. Oleh karna itu pada Restoran Pepper Luch Cabang Central Park Jakarta Barat harus memberikan pelayanan yang optimal, dan lebih maksimal agar pelanggan yang sudah datang bisa kembali berkunjung lagi melalui peningkatan kecermatan dalam pelayanan.

3. Agar terciptanya kepuasan konsumen pada Restoran Pepper luch cabang central park Jakarta barat, bisa memberikan fasilitas tambahan kepada pelanggan seperti WIFI gratis, memberikan potongan harga, serta promosi lainnya yang diharapkan pelanggan merasa puas dan memiliki minat untuk berkunjung kembali.

\section{DAFTAR PUSTAKA}

Algifari. (2015). Analisis Regresi untuk Bisnis dan Ekonomi. Yogyakarta: BPFE.

Amirullah (2015). Pengantar Manajemen. Jakarta: Mitra Wacana Media

Arikunto, Suharsimi (2014). Prosedur Penelitian Suatu Pendekatan Praktek. Jakarta: Rineka Cipta.

Assauri, Sofjan. 2004. Manajemen Pemasaran. Jakarta: Rajawali Press.

Dharmayuni, L., et al. (2021). Effect of Distribution Cost and Promotion Cost 
on Tyre Industries Sales Performance. Annals of the Romanian Society for Cell Biology, 12672-12684.

Erlangga, H., et al. (2019). Pengaruh Kegiatan Promosi Terhadap Keputusan Pembelian Konsumen Pada PT. Modise Busana Sejati Di Bandung. Jurnal Ekonomi Efektif, 1(4), 300-308.

Ghozali, Imam, 2006.“Aplikasi Analisis Multivariate Dengan SPSS". Cetakan keempat. Badan penerbit Universitas Diponegoro, Semarang.

Handoko, 2012, Manajemen Personalia dan Sumber Daya Manusia, Penerbit, BPFE, Yogyakarta.

Haque, M. G., et al. (2021). Micro Financial Sharia Non-bank Strategic Analysis: a Study at BMT Beringharjo, Yogyakarta. Budapest International Research and Critics Institute (BIRCIJournal): Humanities and Social Sciences, $4(2), 1677-1686$.

Hindarsah, I. (2021). The Influence of Service Quality, Emotional Marketing and Spiritual Marketing On Customer Satisfaction. Turkish Journal of Computer and Mathematics Education (TURCOMAT), 12(3), 3685-3689.

Husein Umar. "Metode Penelitian untuk Skripsi dan Tesis Bisnis". PT Raja Grafindo Persada, Jakarta, 2008.

Imam Ghozali (2017), Aplikasi Analisis Multivariase Dengan Program SPSS,Edisi Kelima. Semarang: Badan Penerbit Undip.

Istijanto (2014), Riset Sumber Daya Manusia, Jakarta: PT Gramedia Pustaka.

Kharis, Ismu Fadli. 2011. Studi Mengenai Impulse Buying dalam Penjualan Online. Semarang: Universitas Diponegoro.

Kotler, Philip. 2002. Marketing Management. New Jersey: The Millennium Edition, PrenticeHall International Edition.

Ma'ruf, Hendri. 2005. Pemasaran Ritel. Jakarta: Gramedia Pustaka Utama.
Malhotra, N.K., "Riset Pemasaran", Edisi keempat, Jilid 1, PT Indeks, Jakarta, 2009.

Mowen and Miror, 2005, Perilaku Konsumen, Erlangga, Jakarta. Robbins and Coulter, 2013, Manajemen, Penerbit Erlangga, Jakarta.

Nurjaya, N., Erlangga, H., Jasmani, J., Sunarsi, D., Rifuddin, B., \& Mujahidin, M. (2020). Pengaruh Store Atmosphere Terhadap Keputusan Pembelian Konsumen Pada Starbucks Di Wilayah Cianjur. Jurnal Ekonomi Efektif, 2(4), 637-643.

Rao, Purba. 2012. Measuring consumer perception through factor analysis. The asian.

Safroni, Ladzi. 2012. Manajemen dan Reformasi Pelayanan Publik dalam Konteks Birokrasi Indonesia. Surabaya : Aditya Media Publishing.

Santoso, Singgih. (2015). Mengatasi Statistik Multivarias. Jakarta: PT. Elex Media Komputindo.

Setiawati, N. P. A., Sunarsi, D., Nurjaya, S., Manan, A., Nurhadi, A., Erlangga, H., ... \& Purwanto, A. (2021). Effect of Technology Acceptance Factors, Website Service Quality and Specific Holdup Cost on Customer Loyalty: A Study in Marketing Departement of Packaging Industry. Annals of the Romanian Society for Cell Biology, 12685-12697.

Sugiyono, 2013 Metode Penelitian Pendidikan Pendekatan Kuantitatif, Kualitatif,dan R\&D. Bandung: Alfabeta.

Suhartanto (2014). Metode Riset Pemasaran. Bandung: Alfabeta.

Tjiptono, Fandy dan Gregorius Chandra, 2012. "Pemasaran Strategik", Andi. Yogyakarta.

Yulistiana, I., et al. (2021). Did Brand Perceived Quality, Image Product And Place Convenience Influence Customer Loyalty Through Unique Value Proposition?. Journal of Contemporary Issues in Business and Government, 27(1), 2854-2867. 